\title{
Imination Catalysis via Two-point Binding of Substrate Aldehyde via a Metal and a Pendant Hydrogen-Bonding Group
}

\author{
Dong-Heon Lee, Robert H. Crabtrec, $\div$ and Sang-Kyu Park

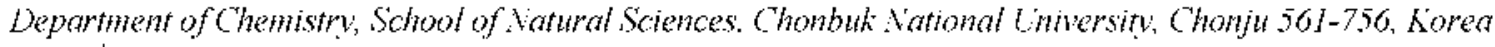

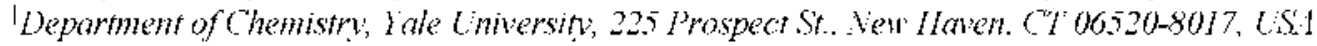

Received 1/arch 12, 2002

Key words : Hydrogen bonding. Imination catalysts. Two-point binding. Aldehyde complex

Imination of carbony 1 compounds is important in heterocycle sinthesis and in the biosynthesis of amino acids ${ }^{1.2}$ but side reactions can occur. such as aninal formation. Both base ${ }^{3}$ and acid catalysts $\left(e, g . \mathrm{ZnCl}_{2}\right)^{+}$are known but these tend to be unselective. Eisch and Sanche\% have reported a uscful aluminum complex capable of selectively catalyzing imination. ${ }^{\text {l }}$

Our interest in metal complexes with pendant hydrogen bonding groups led us to lest [(bq-NHz)]rH( $\left.\left.\mathrm{H}_{2} \mathrm{O}\right)\left(\mathrm{PPh}_{3}\right)_{2}\right]-$ $\left(\mathrm{BF}_{4}\right)$ (1) (bq- $\mathrm{NH}_{2}=2$-aminobcroquinoliatc) $)^{5}$ for calalytic imination. Since we cxpected the aldehyde reagent but not the imine product to bind to the metal. selectivity for imine formation scemed likely. In this study $p$-tolualdehyde (p$\mathrm{ArCHO}$ ) is indeed found to bind to 1 to give a crystalline derivative. $\left[\left(\mathrm{bq}-\mathrm{NH}_{2}\right)\right] \mathrm{rH}\left(p-\mathrm{ArCHO}_{2}\left(\mathrm{PPh}_{3}\right)=\right]\left(\mathrm{BF}_{4}\right)$ (2) (Schemc 1). and imine formation from $p-\mathrm{ArCHO}$ and $\mathrm{MesNH}=(2.4 .6-$ trimethylpheny lamine) is calalyzed by complexes 1 and 2.

The complex 2 was obtained by the reaction of 1 with excess $p$-ArCHO in $\mathrm{CH}_{2} \mathrm{Cl}_{2}$ (Scheme l). Crystallization ol 2 from dichloromethanc/hexanc yiclds single crystals suitable for X-ray structure detcrmination. A summary of crystal paramelers and refinement results is given in Table $I$ and sclected bond lengths and angles are complicd in Table 2 . The ORTEP vicw of the cationic portion of the complex is depicted in Figure 1. The most important fcature of 2 is that the pendant $\mathrm{NH}_{z}$ group is capable of hydrogen bonding to the carbonyl oxygen aton of the aldehyde. Although the $\mathrm{NH}_{2}$ hydrogens are not observed. the $\mathrm{N}-\mathrm{O}$ distance of $2.86 \mathrm{~A}$ is consistent with an $\mathrm{N}-\mathrm{H} \cdots \mathrm{O}$ hydrogen bond. Two

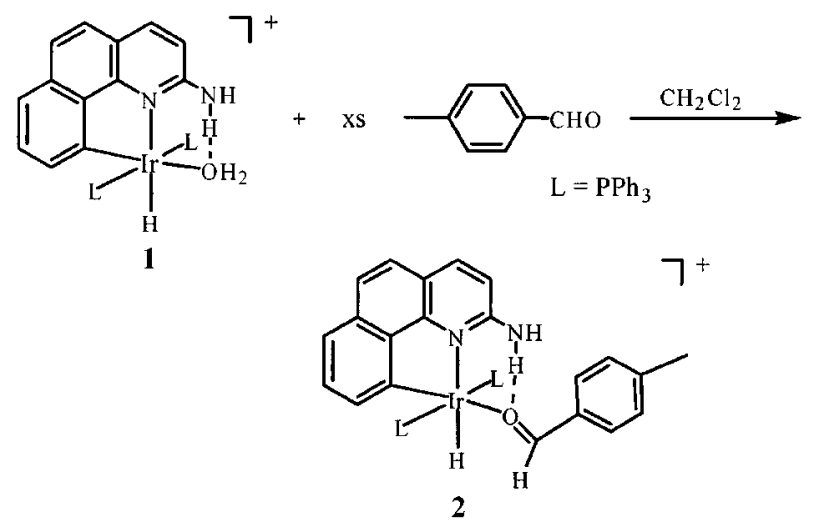

Scheme 1 distinctive $v(\mathrm{NH}) \mathrm{lR}$ bands at 3359 and $3471 \mathrm{~cm}^{-1}$. shifted from the lirec ligand band at $3411 \mathrm{~cm}^{-1}$. also indicate hydrogen bonding. In the ${ }^{\text {}} \mathrm{H}$ NMR spectrum at low temperature (below $-40{ }^{\circ} \mathrm{C}$ ). the $\mathrm{H}$-bonded $\mathrm{NH}$ is observed at $7.70 \mathrm{ppm}$. whereas the non-hydrogen-bonded $\mathrm{NH}$ is observed at 5.85 ppm,

We cxamined cataly tic imination of $p$-ArCHO with $\mathrm{MesNH}_{2}$ in the presence of complexes 1 or 2. When equivalent amounts of $p$-ArCHO and $\mathrm{MesNH}_{2}$ werc treated with 5 mol\% 1 or 2 at $25^{\circ} \mathrm{C}$ in $\mathrm{CD}_{2} \mathrm{Cl}_{2}$ in an NMR tubc (Scheme 2). we found an average ratc of 18 turnovers/hr.

Control reaclions without catalyst or with an $\mathrm{NH}_{3}$ ligand. 3. blocking the $p$-ArCHO binding sitc. showed that no detcctable amount of imine was formed. Thereforc. binding of an aldehyde to the iridium ion secms essential for the imine formation.

We next tested the catalytic imination of $p$-tolualdehyde with an analogous iridium complex. $4{ }^{7}$ lacking a pendant $\mathrm{NH}$ = group. The aqua ligand in + could be casily replaced by

Table 1. Crystallographic data for $2 \cdot \mathrm{CH}_{2} \mathrm{Cl}_{2}$

\begin{tabular}{|c|c|}
\hline liommula & $\mathrm{C}_{8} \mathrm{HI}_{30} \mathrm{~N}_{2} \mathrm{OBH} \cdot \mathrm{P}_{2} \mathrm{Cl}_{2} \mathrm{Ir}$ \\
\hline MW & 1202.92 \\
\hline Timperature, $\mathrm{K}$ & 183 \\
\hline Cṇstal sỵstem & uriclinic \\
\hline Space group & $P_{-1}(\# 2)$ \\
\hline$a(A)$ & $10.1501(2)$ \\
\hline$b(A)$ & $13.0430(3)$ \\
\hline$c(A)$ & $20.7801(5)$ \\
\hline$\alpha x($ degrec $)$ & $96.911(1)$ \\
\hline$\beta$ (degres) & $97.014(1)$ \\
\hline$\gamma($ degree $)$ & $109.373(1)$ \\
\hline$I^{-} A^{3}$ & $2537.5(1)$ \\
\hline$F(000)$ & 1204.00 \\
\hline 2 & 2 \\
\hline Calculalal density, $\mathrm{g} / \mathrm{cm}^{3}$ & 1.574 \\
\hline$\lambda(\mathrm{MoK}(\alpha), \AA$ & 0.71069 \\
\hline Scan lype & $\omega-2 \theta$ \\
\hline Rellections measurod/unique & $220.180 / 14888\left[\mathrm{R}_{\mathrm{int}}=0.036\right]$ \\
\hline $\mathrm{R}^{\prime \prime}$ & 0.033 \\
\hline $\mathrm{R}_{w}^{b}$ & 0.042 \\
\hline Goodness of lit indicator & 1.44 \\
\hline
\end{tabular}


Table 2. Selected bond distances $(\AA)$ and bond angles (") of $2 \cdot \mathrm{Cll}_{2} \mathrm{Cl}_{2}$

\begin{tabular}{|c|c|c|c|}
\hline \multicolumn{4}{|l|}{ Bond lengths } \\
\hline $\operatorname{In}(1)-P(1)$ & $2.3203(7)$ & $\operatorname{Ir}(1)-O(1)$ & $2.197(2)$ \\
\hline $\operatorname{Ir}(1)-C(9)$ & $2.013(3)$ & $\operatorname{Ir}(1)-P(2)$ & $2.345(7)$ \\
\hline $\operatorname{In}(1)-N(1)$ & $2.203(2)$ & $O(1)-C(1)$ & $1.241(4)$ \\
\hline \multicolumn{4}{|l|}{ Bund angles } \\
\hline $\mathrm{P}(1)-\mathrm{I}(1)-\mathrm{P}(2)$ & $170.29(2)$ & $\mathrm{P}(1)-\mathrm{Ir}(1)-\mathrm{N}(1)$ & $95.20(7)$ \\
\hline $\mathrm{P}(1)-\ln (1)-O(1)$ & $90.71(6)$ & $P(1)-\operatorname{Ir}(1)-C(9)$ & $89.94(8)$ \\
\hline$P(2)-\ln (1)-(X)$ & $89.77(6)$ & $\mathrm{P}(2)-\mathrm{Ir}(1)-\mathrm{C}(9)$ & $90.14(8)$ \\
\hline $\mathrm{P}(2)-\operatorname{lr}(1)-\mathrm{N}(1)$ & $94.37(6)$ & $O(1)-\operatorname{Ir}(1)-C(9)$ & $176.60(9)$ \\
\hline$O(1)-\operatorname{lr}(1)-N(1)$ & $96.66(8)$ & $\mathrm{N}(1)-\operatorname{Ir}(1)-C(9)$ & $80.0(1)$ \\
\hline $\operatorname{Ir}(1)-P(1)-C(22)$ & $115.69(10)$ & $\operatorname{Ir}(1)-P(1)-C(34)$ & $118.3(1)$ \\
\hline $\ln (1)-P(1)-(C(28)$ & $109.60(9)$ & $\operatorname{Ir}(1)-P(2)-C(40)$ & $112.7(1)$ \\
\hline $\operatorname{Ir}(1)-P(2)-C(52)$ & $116.57(10)$ & $\operatorname{Ir}(1)-P(2)-C(46)$ & $116.09(9)$ \\
\hline $\operatorname{Ir}(1)-O(1)-C(1)$ & $126.5(2)$ & $\operatorname{Ir}(1)-N(1)-C(19)$ & $130.2(2)$ \\
\hline $\operatorname{Ir}(1)-N(1)-C(20)$ & $111.1(2)$ & $\operatorname{Ir}(1)-C(9)-C(21)$ & $114.5(2)$ \\
\hline $\ln (1)-(9)-(10)$ & $128.9(2)$ & & \\
\hline
\end{tabular}

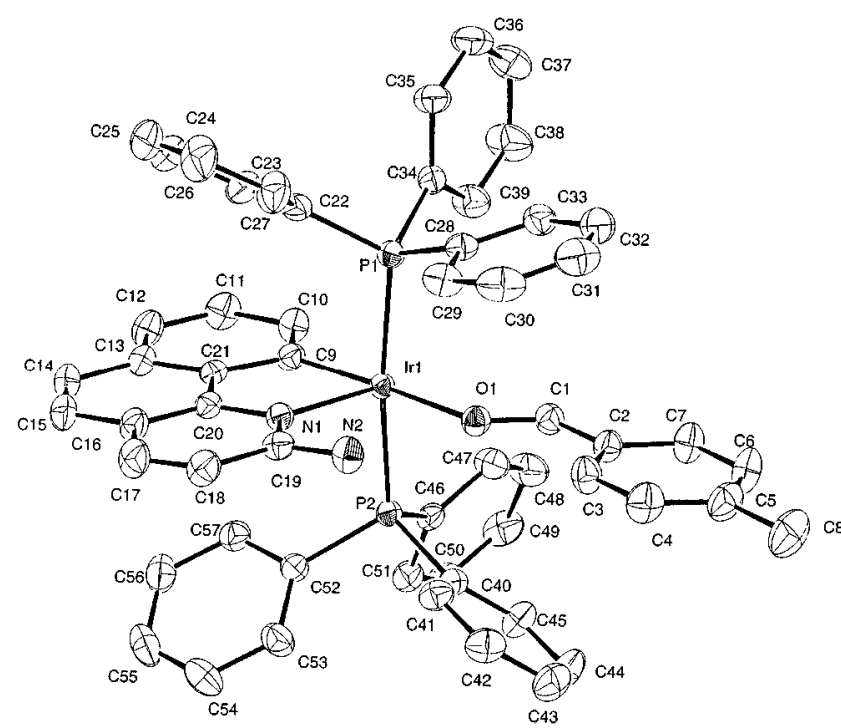

Figure 1. ORTFP view of the cationic pottion of $2 \cdot \mathrm{CH}_{2} \mathrm{Cl}_{2}(50 \%$ ellipsids).

$p$-tolualdelyde and the spectroscopic data of the resulting compound revealed that the carbonyl oxygen atom of the aldehyde was bound to the iridium ion. However, the rate of catalytic imine formation for $p$-tolualdehyde with $\mathrm{MesNH}_{2}$ was only 14 turnovers/lu with the catalyst 4 small but significant rate decrease in comparison with the complex 1 .

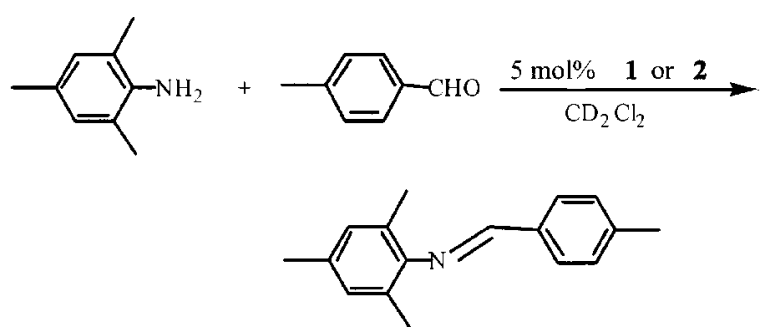

Scheme 2

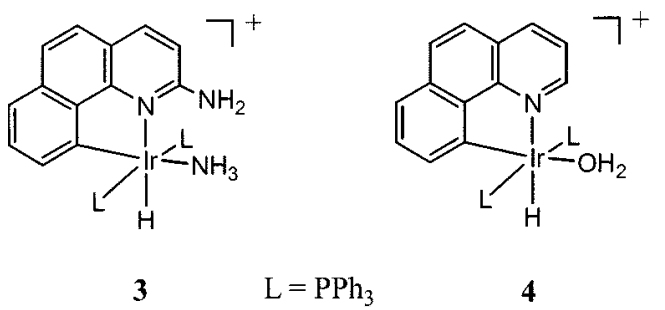

Therefore. the presence of the H-bonding group in 1 secms to be responsible lor the enhanced catalytic activity. Another control studies was performed with mesitaldehyde (2.4.6trimethy lbenzaldehyde). We expected the two bulky methyl groups at the 2-and 6-carbon positions in the phenyl ring to present the aldchyde group from $\mathrm{H}$-bonding to the pendant $\mathrm{NH}_{2}$ in 1. due to steric repulsion between the methyl groups and the $\mathrm{NH}_{2}$. This was. indecd. conlirmed by NMR and IR spectroscopic studics. showing no interaction between the $\mathrm{N}-\mathrm{H}$ and $\mathrm{C}=\mathrm{O}$ groups in the complex generated (in simi) from the reaction of mesitaldehyde and 1. As cxpected. the mesilaldelyde imination of $\mathrm{McsNH}_{2}$ with the catalyst 1 resulted in no improvement at all in catalytic activity $(6$ turnovers/hr). in comparison with the catalyst 4 ( 6 turnovers/ hr).

In summary a small cnhancement in catalytic activity has becn achicicd via two-point binding of substrate aldchyde. Screral interesting catalytic reactions have becn suggested to procecd vio a pathway involv ing cooperative coordination of a carbonyl group by two Lewis acidic metal centers. ${ }^{80}$ Our studics. however. represents the first time a carbonyl has becn activated in a two-point fashion via a coordinate metal$\mathrm{O}$ bond and an $\mathrm{N}-\mathrm{H} \cdots \mathrm{O}$ hydrogen bond. as far as we know. The relatively modest rate increase for 1 or 2 w. + may indicate that hydrogen bonding stabilizes the transition state (ts) only slightly more than it does the ArCHO complex (the ground state). Selective stabilization of the ts is required for significant catalytic acceleration by hydrogen bonding. There must therefore be a subtle mismatch between the lyddrogen bonding pendant group to give weak binding in the ground state but a match in the ts. Further study will focus on the effects of a pendant hydrogent-bonding group on homogeneous catalysis for other important organic reactions.

\section{Experimental Section}

Reagents and solvents were of conunercially available reagent quality. Preparation and handling of Ir complexes were carried out under argon with standard Schlenk tecluiques. ' $\mathrm{H}$ NMR spectra were measured in $\mathrm{CDCl}_{3}$ or $\mathrm{CD}_{2} \mathrm{Cl}_{2}$ on a Bruker $(300 \mathrm{MHz})$ NMR spectronleter. Infrared spectra were recorded neat or in Nujol nulls on a Mattsolı Galasy $4030 \mathrm{FT}$-IR spectrometer.

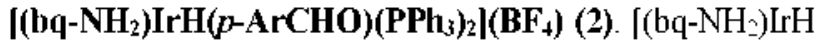
$\left.-\left(\mathrm{H}_{3} \mathrm{O}\right)\left(\mathrm{PPl}_{3}\right)_{2}\right)\left(\mathrm{BF}_{4}\right)(\mathbf{1})(0.4 \mathrm{~g} .0 .39 \mathrm{mmol})$ was dissolved in $10 \mathrm{~mL}$ of degassed $\mathrm{CH}_{2} \mathrm{Cl}_{2}$ under Ar in a Scluenk flask. To the clear yellow solution was added $p$-tolualdelyde $(0.4 \mathrm{~g}$. 
$3.3 \mathrm{mmol}$ ) and the resulting mixture was stirred at room temperature for $20 \mathrm{~min}$. A mixture of hexane/diethyl ether (50/50) was added until the solution became cloudy. The solution was filtered and more hexane/diethyl ether was added to precipitate yellow cry stalline solid. The solid was collected by filtration, washed with diethyl ether. The product was recrystallized in $\mathrm{CH}_{2} \mathrm{Cl} / \mathrm{El}=\mathrm{O}$ and dried in vacto. Yield: $0.32 \mathrm{~g}(75 \%)$. ${ }^{l} \mathrm{H}$ NMR $\left(\mathrm{CD}_{2} \mathrm{Cl}_{2,} 300 \mathrm{MH} / 293 \mathrm{~K}, \mathrm{ppm}\right): \delta$ $-16.18\left(1.1 \mathrm{H}_{0}{ }^{2} \mathrm{~J}_{\mathrm{IIP}}=14.6 \mathrm{H} / \mathrm{lr}-\mathrm{H}\right) .2 .38\left(\mathrm{~s} .3 \mathrm{H} . \mathrm{CH}_{3}\right) .6 .36$ (br. s. $1 \mathrm{H} . \mathrm{N}-\mathrm{H}$ ). 6.60-7.42 (m. 42H). 9.98 (br. s. CHO). ${ }^{31} \mathrm{P}{ }^{1}{ }^{1} \mathrm{H}$; NMR $\left(\mathrm{CD}_{2} \mathrm{Cl}_{2,} 125 \mathrm{MH} / .293 \mathrm{~K}\right.$. ppm) $\delta 20.3(\mathrm{~s})$. IR (thin-film. $\left.\mathrm{cm}^{-1}\right): v .1595(\mathrm{C}=\mathrm{O}) .2197(\mathrm{Ir}-\mathrm{H}), 3359$ $(\mathrm{NH})$. 347l $(\mathrm{NH})$. Anal. Calc. for $\mathrm{C}_{57} \mathrm{H}_{48} \mathrm{~N}_{2} \mathrm{OBF}_{4} \mathrm{P}_{2} \mathrm{lr}$ : C. 61.20: H. 4.29: N. 2.51. Found: C. 61.62: H. 4.32: N. 2.36.

X-ray Crystallograply. A ycllow colunn crystal of $2 \mathrm{CH}_{2} \mathrm{Cl}_{2}$ having approximate dimensions of $0.12 \times 0.12 \times 0.20 \mathrm{~mm}$ was mounted on a glass fiber. All measurements were made on a Nonius KappaCCD diffractometer with graphite monochromatcd Mo- $\mathrm{K} \alpha$ radiation. Cell constants and an oricntation matrix for data collcction were obtaincd from lcastsquares refinement. using $1 \mathrm{cn}\left(\mathrm{l}^{\circ}\right.$ in $6.10 \mathrm{l}$ s exposurc. dezingered) data frames. The data were collected at a temperature of $-90^{\circ} \mathrm{C}$ to a maximum $2 \theta$ value of $61.0^{\circ}$. Of the 22080 reflections that were collected. 14888 were unique $($ Rint $=0,036)$ : cquivalent reflections were merged. No decay: correction was applied. The linear absorption cocllicicnt. $\mu$. for Mo-K $\alpha$ radiation is $28.6 \mathrm{~cm}^{-1}$ and a SORTAV ${ }^{16}$ absorption correction was applied. The data were corrected for Lorenty and polarization effects. The structure was solycd by heavy-atom Patterson method and cxpanded using Fouricr techniques. The non-lyddrogen atoms were refined anisotropically. Hydrogen atoms were included but not refined. The $\mathrm{NH}_{\Sigma}$ bydrogens were included in difference map positions. but not refined. The Ir-H was not observed in the diflerence map. A summary of cristal parameters and relinement results is given in Table 1. Crystallographic data for the structure reported here have been deposited with the Cambridge
Crystallographic Data Centre (Deposition No. CCDC183971). The data can be obtained free of charge via http: w'w'ccdscamacuk conts retreininght (or from the CCDC. 12 Union Road Cambridge CB2 IEZ. UK: lax: ++4 1223 336033: c-mail: depositáaccdc.cam.ac.uk)

Catalytic Turnover Measurement. Typically. cquimolar (0.3 mmol) ArCHO and MesNH $\mathrm{NH}_{2}$ were placed in a NMR tube containing $\mathrm{CD}_{2} \mathrm{Cl}_{2}(0.6 \mathrm{~mL})$ with $5 \mathrm{~mol} \%$ cataly $\mathrm{st}(15$ $\mathrm{mol}$ ). Imine formation was followed by the disappearance of the $-\mathrm{CH}=\mathrm{O}$ resonance at $9.98 \mathrm{ppm}$ and the appearance of the imine $-\mathrm{CH}=\mathrm{N}$ resonance at $8.16 \mathrm{ppm}$. All reactions were rum at least in triplicate and the data reported represent the average of these reactions.

Acknowledgment. This work was financially supported by the Korca Science and Enginecring Foundation (R052002-(000-(01]72-(0) and the National Science Foundation. We thank Dr. Susan de Gala for the X-ray structure determination.

\section{References}

1. Eisch. I. I.: Sanchez. R. J. Org. Cheme. 1986. 5J. 1848.

2. Joule. I. A. Smith. G. I. Hetrocsiclic Chemistms. $2^{\text {nal }}$ ed: Van Nostrand Reinhold: New York. 1978, p 74

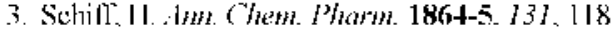

4. Reddelien. G. Ber. Chem. 1913. +6.2721.

5. Gruct. K.: Crabtrec R. H.: Lee. D.-H.: Liable-Sands. L. M.: Rheingold. A. L.: Crabtree. R. H. Orgmometallics 2000. 19. 2228

6. Jellirey. (i. A.: Saenger. W. Hydrogen Bonding in Biological Sistons Springer: I3erlin. 1994

7. Crabtrec. R. H.: Lavin. M.: Bonncviot. L. J. Am. C/km. Soc. 1986. 108. 4032 .

8. Ooi. T.: Itagaki. Y.: Miura. T.: Maruoka. K. Tetrohedron Lett. 1999.40 .2137$.

9. I lanawa. II.: Maekawara. N.: Maruoha. K. Tetrahedron left. $1999.40,8379$.

10. Blessing. R. H. Acta Cnst 1995. .451.33. 